\title{
Rossica teatralne na łamach prasy Polski międzywojennej. Teatr radziecki i jego twórcy ${ }^{1}$
}

\author{
Grażyna PAWlak \\ (Instytut Badań Literackich PAN, Warszawa)
}

Powiązania i wpływy artystyczne między teatrem polskim i rosyjskim sięgają początku XX wieku. Twórcy, którzy zaważyli na rozwoju teatru polskiego w Drugiej Rzeczypospolitej, artystyczną działalność rozpoczynali jeszcze przed pierwszą wojną światową (Arnold Szyfman, Leon Schiller, Juliusz Osterwa, Stefan Jaracz, Aleksander Zelwerowicz). Wspólne ongiś granice Imperium ułatwiały poznawanie dorobku teatralnego wschodniego sąsiada. Gościnne występy teatrów z Moskwy i Petersburga w Warszawie nie należały do rzadkości, nieliczni mogli oglądać spektakle na macierzystych scenach w Rosji. Nawiązywano instytucjonalne i prywatne kontakty, a polskie zespoły chętnie prezentowały swój dorobek za wschodnią granicą. Teatr Narodowy w Warszawie także odbywał tournée artystyczne po ziemiach Cesarstwa. W roku I9ı2 roku odwiedził Kijów, Mińsk i Petersburg, prezentując takie perełki swojego repertuaru jak Zemsta Aleksandra Fredry, Cyganeria warszawska Adolfa Nowaczyńskiego czy Wesele Stanisława Wyspiańskiego. Jego inscenizacje w roku I9I3 porównywano z berlińskimi i moskiewskimi, Arnolda Szyfmana nazywano zaś w gazetach niemieckich „warszawskim Reinhardem”, a w rosyjskich „polskim Stanisławskim”. Kolejne wielkie tournée Teatru Narodowego po Rosji, rozpoczęte w roku I9I4, przerwał wybuch wojny, która zatrzymała zespół w stolicy Imperium na kilka lat. Podczas przymusowego pobytu artyści polscy korzystali z przychylności i gościnności Konstantego Stanisławskiego, twórcy Moskiewskiego

1 Artykuł powstał w ramach kierowanego przez dr hab. Annę Sobieską projektu „Spojrzenie z ukosa...”. Kultura i literatura rosyjska oczami Polaków (na materiale czasopism polskich okresu międzywojennego). Grant NCN umowa nr UMO-2012/07/E/HS/03861.

2 H. Wisner, Z historii stosunków kulturalnych polsko-radzieckich 1919-1939, Warszawa 1987, s. 66. 
Teatru Artystycznego (MChAT-u), który zaprosił członków zespołu do siedziby swojego teatru, by tam mogli pracować i prezentować swój dorobek. Wówczas doszło do bliższej współpracy z założycielem MChAT-u i z tego okresu wywodzi się fascynacja Osterwy metodą Stanisławskiego oraz inspiracja do założenia polskiego teatru eksperymentalnego. Po latach, oceniając rolę i wpływ Stanisławskiego na teatr polski, Stefan Jaracz pisał: „co tu ukrywać i nasza «Reduta» urodziła się w Moskwie"3. Identyczna myśl przewija się we wspomnieniach Aleksandra Zelwerowicza, który z przekonaniem dowodził, że „długi pobyt naszych czołowych ludzi teatru (a przede wszystkim Juliusza Osterwy) w Moskwie stał się źródłem narodzin idei stworzenia w Warszawie rewolucyjnej imprezy teatralnej [...] innymi słowy stał się sprawcą narodzin Reduty"4. Paradoksalnie, wydarzenia historyczne i okres Wielkiej Wojny stworzyły fundament, na którym w wolnej Polsce można było budować wzajemne relacje. Te przetrwały mimo rozmaitych fluktuacji politycznych. Dowodem ich żywotności w sferach artystycznych było nie tylko zaproszenie przedstawicieli polskiego teatru w osobach Leona Schillera i Aleksandra Zelwerowicza na obchody jubileuszu trzydziestolecia MChAT-u, ale też nadzwyczaj serdeczne przyjęcie, z jakim się spotkali. Mimo imponującej liczby gości z całego świata, wśród których błyszczały takie gwiazdy jak Max Reinhard, Aleksander Moissi, Gerard Hauptmann, Charlie Chaplin, po przemówieniu Schillera (wygłoszonym po francusku, na język rosyjski nie zgadzała się bowiem cenzura) Stanisławski poruszony fragmentem traktującym o szczególnych wyrazach wdzięczności za przyjacielskie przyjęcie, jakie polskim artystom przygotowali twórcy i współpracownicy MChAT-u w okresie ich przymusowego pobytu w Moskwie, podszedł do polskich delegatów i ściskając ich dłonie, ze wzruszeniem wypowiedział słowa, które były dowodem głębokiej i szczerej przyjaźni: „dziękuję serdecznie moim przyjaciołom i najbliższym wspólpracownikom, Polakom!’’.

Słowa te kierował do polskich delegatów twórca, który odcisnął najsilniejsze piętno na rosyjskiej scenie teatralnej schyłku XIX i pierwszych dekad XX wieku. Konstantin Stanisławski oraz jego wybitni uczniowie: Wsiewołod Meyerhold, Nikołaj Jewreinow, Aleksandr Tairow i Eugeniusz Wachtangow zdecydowali o jej kształcie i rozwoju ${ }^{6}$. Każdy z nich na swój sposób rzucał wyzwanie zastanemu konwenansowi teatralnemu. Trudno nie przyznać racji polskiemu sprawozdawcy, który trzy lata przed śmiercią Stanisławskiego pisał: „Nie byłoby Meyerholda,

3 S. Jaracz, Krzewienie kultury teatralnej, „Wiadomości Literackie” 1934, nr 39, s. 4. We wszystkich cytatach źródłowych zachowano pisownię i interpunkcję oryginału.

4 A. Zelwerowicz, Gawędy starego komedianta, Warszawa 1958, s. 105.

5 Idem, Święto teatralne w Moskwie, „Tygodnik Ilustrowany” 1928, nr 47, s. 870.

6 T. Kudliński, Teatr powszechny, „Przegląd Współczesny” 1937, t. 60, s. 37. 
Wachtangowa, Tairowa i wielu innych wielkich nazwisk aktorskich i reżyserskich, gdyby nie Stanisławski. Nie byłoby nawet naszej «Reduty», która z kolei zapłodniła inne polskie poczynania sceniczne"”.

Stanisławski całą swoją uwagę skupił na sztuce aktorskiej, czyniąc z niej przedmiot systematycznych badań. Stworzył metodę pracy opartą na osiągnięciach ówczesnej psychologii, w szczególności pamięci uczuć, opisanej przez Théodule Ribota ${ }^{8}$ z której oprócz tez zaczerpnął również terminologię (pamięć afektywna, pamięć emocjonalna). Najważniejszym celem, jaki sobie postawił i do którego konsekwentnie zmierzał, było ciągłe doskonalenie gry aktorskiej dzięki ćwiczeniu pamięci emocjonalnej i sensualnej. Stworzony przez niego system wskazywał aktorowi, jak wysiłkiem woli wytworzyć w sobie uczucia kreowanej postaci. Założyciel Moskiewskiego Teatru Artystycznego ${ }^{9}$ głosił, że „sztuka aktorska nie jest trickiem technicznym ani powierzchownym portretowaniem postaci czy akcji” ${ }^{\circ}$, ale rządzą nią takie same prawa jak w naturze, bez względu na to, czy powstać ma fenomen biologiczny czy imaginacyjny. Kreację aktorską porównywał do „poczęcia i narodzenia nowej istoty: bohatera roli” $i$ uważał, że ,jest to akt analogiczny do urodzenia człowieka”, bo „każda dramatyczna postać stworzona na scenie - jest istotą jedyną i niepowtarzalną, jak dzieła natury" - notował w Myślach o twoórczości aktorskiej ${ }^{\text {II }}$. By sprostać tak postawionemu zadaniu, zmienił metody pracy: zerwał z dziewiętnastowiecznym modelem teatru, który promował aktorów solistów, oraz z podziałem na wielkie i małe role. Stworzył zespól, w którym nie tylko wszyscy byli równi, ale i wszystkie postacie inscenizacji były opracowywane $\mathrm{z}$ taką samą starannością. Analizę rozpoczynano od studiowania wewnętrznego życia bohaterów i dyskusji nad tym, jak je oddać w wewnętrznym procesie przeżywania. Według Stanisławskiego kluczem do właściwej interpretacji roli była umiejętność całkowitego zespolenia się z postacią, ponieważ tylko w ten sposób aktor może osiągnąć prawdę emocjonalną, bo pokazywać można tylko to, co się zna samemu, nie z opowieści ${ }^{\mathrm{I2}}$. Aby w pełni zrozumieć ducha epoki i osadzonych w niej postaci, przeprowadzano drobiazgowe badania w muzeach, bibliotekach, szukano także wzorców w codziennym życiu.

7 B. Dąbrowski, Mezalians Meyerholda i - spotkanie ze Stanistawskim. (Obrazki z Festiwalu w Moskwie), "Chwila” 1934, nr 26, s. 6.

8 Théodule Ribot (1839-1916), autor licznych prac z zakresu psychologii, w tym Choroby woli, O wyobraźni twórczej. Studium psychologiczne, Psychologia uczuć.

9 Od początku roku placówka działała pod nazwą Moskowskij Chudożestwiennyj Tieatr. Od 1920 r. na polecenie Anatolija Łunaczarskiego, ówczesnego ludowego komisarza oświaty, została zaliczona do grupy teatrów akademickich i przekształcona w MChAT - Moskowskij Chudożestwiennyj Akademiczeskij Tieatr (Moskiewski Teatr Artystyczny).

10 K. Stanisławski, Myśli o twórczości aktorskiej, tłum. W. Melcer, „Scena Polska” 1938, z. 2/3, s. 310.

11 Ibidem.

12 Idem, Moje życie w sztuce, thum. Z. Petersowa, Warszawa 1951, s. 430. 
Równie wiele uwagi poświęcano stronie wizualnej: dekoracje i kostiumy były naturalistyczne, nierzadko olśniewały przepychem, co w dużej mierze było zasługa jednego z udziałowców Teatru Artystycznego oraz jego wielkiego entuzjasty, moskiewskiego milionera i mecenasa sztuki Sawwy Morozowa ${ }^{\text {133 }}$.

Oryginalnego dzieła Stanisławskiego widownia odrodzonej Polski nie miała szansy docenić. Artysta odwiedził Warszawę po raz pierwszy w maju I9o6 roku, w drodze powrotnej z tryumfalnych występów zespołu w Austrii i Niemczech. W Teatrze Wielkim zaprezentował wówczas inscenizacje dramatów Antoniego Czechowa (Wujaszek Wania), Aleksego K. Tołstoja (Car Teodor) i Maksyma Gorkiego (Na dnie). Jednak atmosfera polityczna nie sprzyjała wizytom rosyjskich zespołów, ponieważ traktowano je jako kolejny symbol narzucanej przez zaborcę przemocy. Toteż publiczność warszawska zbojkotowała występy, na sali pojawili się jedynie aktorzy, krytycy i znawcy teatru. Ci o sztuce Stanisławskiego wyrażali się z entuzjazmem, choć także i u nich zastrzeżenia budziła decyzja przyjazdu. Niektórzy sprawozdawcy czuli się w obowiązku wytłumaczyć rosyjskiemu artyście powody tej absencji. Jan Lorentowicz opublikował list otwarty do Stanisławskiego, wyjaśniając, że w czasach, gdy „,uniwersytety nasze zamknięte, szkoły rozpędzone, a stan wojenny zaciążył grozą kar administracyjnych”, teatr zaś oddany w „pod opiekę dyrekcji, nieznającej nawet języka naszego" chyli się ku całkowitej ruinie, jest za wcześnie, by tak wielki artysta, a zarazem przedstawiciel narodu ciemiężyciela był przez mieszkańców Warszawy przyjmowany entuzjastycznie ${ }^{\text {I4 }}$. Polacy zbyt długo byli poddawani zabiegom rusyfikacyjnym (tę rolę przejmowały także trupy rosyjskie przyjeżdżające do kraju), by takie wizyty nie przywodziły na myśl złych skojarzeń. Krytyk kończył swój list wyrazami nadziei, że w niedługim czasie, gdy artysta przybędzie do Warszawy „w przyszłej, autonomicznej Polsce", publiczność właściwie oceni przełomowe osiągnięcia jego teatru ${ }^{15}$. Wypowiedzi Lorentowicza sekundował Władysław Rabski, podkreślający, że choć Stanisławski nie jest politykiem, a artystą, to jeszcze zbyt wcześnie na wizytę, ponieważ w duszy polskiej nadal jątrzy się „,rana niezagojona”, ale „gdy wybije godzina swobody [...] wtedy przyjdź Ty do nas i śpiewaj nam pieśni swojego narodu, a Polska autonomiczna słuchać będzie w zachwycie, niezmąconym żadną myślą uboczną" ${ }^{\text {"16 }}$. Jednak te nadzieje nie miały się nigdy spełnić - kolejna wizyta Teatru Stanisławskiego w Warszawie, w maju I9ı2 roku, niewiele różniła się od tej sprzed sześciu lat. Prasa warszawska niemal wszystkie przedstawienia w Teatrze Wielkim zbywała milcze-

13 F. Pajączkowski, Konstanty Stanistawski i jego wizyta w Polsce, „Ruch Słowiański” 1938, nr 12, s. 217-219.

14 J. Lorentowicz, List otwarty do p. Stanistawskiego, dyrektora teatru rosyjskiego, „Nowa Gazeta” 1906, nr 213, s. 2.

15 Ibidem.

16 W. Rabski, $Z$ teatru, „Kurier Warszawski” 1906, nr 128, s. 2. 
niem, a dał ich zespół podczas dwutygodniowego pobytu czternaście, prezentując m.in. Wiśniowy sad i Trzy siostry Czechowa, Żywego trupa Tołstoja, Miesiac na wsi Turgieniewa, Braci Karamazow Dostojewskiego. Jedynie „Kurier Poranny” postanowił zamieszczać recenzje pióra Kazimierza Ehrenberga. Nie było też przyjaznego odzewu ze strony artystów i krytyki. Rozsyłane przez Stanisławskiego bilety z zaproszeniem na występy zwracano z kurtuazyjnym podziękowaniem. Dla artysty musiało to być powodem głębokiego rozżalenia, choćby dlatego, że - jak pisał jeden $\mathrm{z}$ uważnych obserwatorów rosyjskiej sceny - „Polskość otoczona była w jego teatrze wielkim szacunkiem. Znano tam i ceniono Reymonta, Żeromskiego, a Balladynę w tłumaczeniu Balmonta umiano na pamięç”ㄲ. I tym razem przeważały względy polityczne, chodziło o to, by publiczność nie pojawiała się tłumnie na przedstawieniach teatru rosyjskiego, gdyż to mogłoby być wykorzystane przez urzędników jako argument do założenia stałej sceny rosyjskiej w Warszawie.

W wolnej Polsce Teatr Artystyczny pod wodzą Stanisławskiego nigdy nie zagościł $\mathrm{z}$ występami. $\mathrm{U}$ progu lat dwudziestych w pismach codziennych pojawily się komunikaty, przedrukowane za radziecką gazetą „Poslednije nowosti”, że zespół Stanisławskiego nie otrzymał zgody rządu polskiego na przyjazd. Informacje wydawały się tak absurdalne, że nawet najważniejsze pismo teatralne „Scena Polska” wątpiło w ich prawdziwośćc ${ }^{18}$. Nie udało się ostatecznie rozstrzygnąć, dlaczego Moskiewski Teatr Artystyczny, wielokrotnie udając się na tournée za granicę, nie otrzymał zgody na występy w Warszawie - być może przeważyła szeroko rozpowszechniona obawa przed destrukcyjnym wpływem ideologii bolszewickiej? O sukcesach zespołu Stanisławskiego i jego licznych podróżach, w tym do Pragi czeskiej, Anglii, Skandynawii, a nawet do Stanów Zjednoczonych, publiczność polska była systematycznie informowana za pośrednictwem najważniejszego pisma teatralnego w kraju ${ }^{19}$. W połowie lat trzydziestych nadzieja na wizytę teatru radzieckiego w Polsce odżyła ponownie. W 1934 roku prowadzono nawet rozmowy w sprawie wymiany zespołów teatralnych między obu krajami z Konstantinem Mironowem, reżyserem Teatru im. Wachtangowa, Arnoldem Szyfmanem, dyrektorem Towarzystwa Krzewienia Kultury Teatralnej, i Juliuszem Kadenem-Bandrowskim. Mimo podjętych wstępnych ustaleń i doprowadzenia do spotkania na szczeblu ministerialnym oraz deklaracji dobrej woli z obu stron inicjatywa zakończyła się fiaskiem $^{20}$. Był to ostatni poważny krok poczyniony w tej sprawie przed

17 T. Hiż, Ryszard Bolestawski w Rosji, „Scena Polska” 1937, z. 1-4, s. 51.

18 H. Wisner, op. cit., s. 70.

19 [B. a.], Podróże teatru Stanistawskiego, „Życie Teatru” 1922, nr 2, s. 15.

20 L. Jabłonkówna, Reżyser Mironow o Teatrze im. Wachtangowa, „Wiadomości Literackie” 1934, nr 32, s. 4; [b. a.], Na występy do Moskwy jedzie z Warszawy zespót 40 artystów, „Republika” 1934, nr 192, s. 4; H. Wisner, op. cit., s. 72 . 
radykalnym pogorszeniem stosunków polsko-radzieckich, w związku z represjami stosowanymi w ZSSR wobec swoich obywateli, a także Polaków tam przebywających. Po śmierci Stanisławskiego (1938 rok) artyści polscy oddali hołd wielkiemu reformatorowi teatru na łamach branżowego pisma „Scena Polska” ${ }^{2}$.

Namiastką dla polskiego widza pozostały przedstawienia emigracyjnego zespołu, tzw. Praskiej Grupy Teatru Stanisławskiego, która odwiedziła Polskę dwukrotnie. Po raz pierwszy w lipcu 1928 roku przyjechała do Krakowa i zaprezentowała wystawianego z sukcesem w Paryżu Wujaszka Wanię Czechowa, a w roku następnym zjawiła się w Warszawie z inscenizacjami dramatów Czechowa (Wujaszek Wania i Wiśniowy sad), Gorkiego (Na dnie), Ostrowskiego (Bieda nie hańbi) i Tołstoja (Żywy trup). Recenzujący przedstawienia Słonimski wyraził wówczas pogląd, że obecnie zespół jest zaledwie „słabym cieniem dawnej świetności”, a jednak udało mu się podbić serca warszawskiej widowni ${ }^{22}$.

Mimo iż polscy miłośnicy Melpomeny nie mogli oglądać przedstawień rosyjskich zespołów pracujących według metody Stanisławskiego, to na bieżąco byli informowani o repertuarze Moskiewskich Teatrów Artystycznych (tym mianem określano kilka scen działających w radzieckiej stolicy, w tym także Studio Wachtangowa). Anonsowano drugą po rewolucji premierę w Teatrze Artystycznym, jaką był Rewizor Gogola w reżyserii Stanisławskiego (192I). U znawcy sceny rosyjskiej, który w I922 roku miał okazję obejrzeć występy wielu moskiewskich zespołów w macierzystych teatrach, zdumienie i niesmak wywołała nie tylko jawna chęć wpisania zasłużonego teatru w polityczne oczekiwania, ale także koncepcja roli głównego bohatera, który z rewizora samozwańca zastał zamieniony w pospolitego idiotę:

》 W starym [przedrewolucyjnym - G. P.] Teatrze Artystycznym nie było gry dla galerii - teraz z gry dla galerii robi się całą treść nowego programu artystycznego. [...] Zamiast klasycznego stylu wysokiej komedii - obfitość błazeństw cyrkowych, a na dodatek jeszcze typowo wiecowe gesty, dobre dla mityngów na Placu Czerwonym koło Kremla, ale nie dla Teatru Artystycznego [...]. Bohater Gogola mędrcem nie jest, aleć chyba jest - co się zowie spryciarzem. To jednak chodziło o łatwy śmiech dla udostępnienia Muzy komicznej masom, a łacniej niż z kretyna oczywiście śmiać się nie można - chyba z człowieka pijanego ${ }^{23}$.

21 „Scena Polska” 1938, z. 2/3.

22 as [A. Słonimski], Moskiewski teatr artystyczny $w$ Warszawie, „Wiadomości Literackie” 1929, nr 21, s. 4.

23 R. Dyboski, Wrażenia z teatrów moskiewskich, „Przegląd Warszawski” 1922, nr 5, s. 205. 
W maju 1926 roku zarówno stołeczne „Wiadomości Literackie”, jak i krakowski „Kurier Literacko-Naukowy” donosiły, że MChAT zamierza wystawić Biatq grwardię Bułhakowa, sztukę „osnutą na wypadkach z epoki Petlury”, a rolę hetmana miał kreować znany rosyjski aktor Wasilij Kaczałow ${ }^{24}$. Na propozycję MChAT-u, który poszukiwał sztuk współczesnych, powieść Bułhakowa została przez autora adaptowana na potrzeby teatru i nazwana podtytułem oryginału - Dni Turbinów. I powieść, i opartą na jej materiale sztukę rodzima krytyka odebrała jako „apologię białego obozu” oraz domagała się, w ramach „rozbicia bułhakowszczyzny”, zdjęcia jej z afisza. Dopiero po interwencji Stalina, który uznał, że sztuka Dni Turbinów nie może być zła, „bowiem więcej przynosi pożytku, niż przyczynia szkód”, pozwolono MChAT-owi na jej wznowienie. Krytyka radziecka, starając się pozostać w duchu wypowiedzi Stalina, który - według protokołów spektakli - „oglądał tę sztukę co najmniej piętnaście razy”, zgodnie twierdziła, że jej powodzenie „nie było zasługa dramaturga, lecz teatru, który zdobył je wbrew tendencjom sztuki i jej rzekomo fałszywym założeniom”25.

Jan Hempel, który z uwagą obserwował ruch teatralny i produkcję dramatyczną w porewolucyjnej Rosji, pozostawał pod wrażeniem pierwszego utworu współczesnego wystawionego w Studiu im. Wachtangowa, jakim była adaptacja opowiadań Wiryneja Lidii Sejfulliny, którą uznał za świetne przedstawienie w duchu Stanisławskiego. Lewicowy publicysta, zachwycony kierunkiem rozwoju wypadków na rosyjskiej scenie politycznej i kulturalnej, uważał, że „teatralność musiała stać się jednym ze szczególnych znamion tej kolosalnej demokracji”, a współczesny teatr najpełniej rozkwita, gdy sięga po tematy najbardziej poruszające przeciętnego człowieka ${ }^{26}$. Piszący te słowa Hempel po niespełna dekadzie dołączył do grona ofiar czystek stalinowskich lat trzydziestych.

Przeciw naturalizmowi scenicznemu propagowanemu przez Stanisławskiego wystąpił jego uczeń i niedawny współpracownik Wsiewołod Meyerhold, który jeszcze przed Wielką Wojną dał się poznać jako twórca teatru awangardowego, a po przewrocie bolszewickim był pierwszym reżyserem, który otwarcie zadeklarował się po stronie rewolucji. $Z$ jego nazwiskiem kojarzą się nowatorskie tendencje artystyczne w teatrze radzieckim lat dwudziestych XX wieku. Meyerhold dążył do stworzenia teatru umownego, polemicznego wobec „systemu” Stanisławskiego ${ }^{27}$.

24 [B. a.], Sztuka o Petlurze, „Wiadomości Literackie” 1926, nr 18, s. 3; [b. a.], Moskiewski Teatr Artystyczny, „Kurier Literacko-Naukowy” 1926, nr 19 (127), s. 4.

25 S. Pollak, Srebrny wiek i później, Warszawa 1971, s. 163.

26 J. Hempel, Propaganda sztuki u naszych wschodnich sąsiadów. Teatr i kino w Rosji sowieckiej, „Wiadomości Literackie" 1926, nr 18, s. 2.

27 N. Piesoczinski, Wsiewotod Meyerhold. Teoria względności, tłum. A. L. Piotrowska, „Pamiętnik Teatralny” 2001, z. 3-4, s. 8 i inne. 
Uważał, że teatr jest sztuką autonomiczną i zbiorową, a jednocześnie ściśle związaną z celami rewolucji, w której zwycięstwie widział ogromne szanse jego rozwoju. Jeszcze w okresie pracy nad inscenizacjami dramatów symbolicznych Meyerhold zapoznał się ze studium Heinricha von Kleista O teatrze marionetek, które w opinii pewnych badaczy można uznać za ważne odniesienie dla biomechaniki ${ }^{28}$. Być może myśl Kleista o poszukiwaniu możliwości przekraczania ograniczeń ciała przez wykorzystanie sił mechanicznych zachęciła twórcę do eksperymentowania? Wkrótce Meyerhold stał się apologetą ruchu na scenie, entuzjastą komedii improwizowanej, komedii dell'arte, pantominy i cyrku ${ }^{29}$, a także japońskiego teatru kabuki. Stworzona przez niego koncepcja biomechaniki z jednej strony czerpała $\mathrm{z}$ tradycyjnych konwencji teatralnych komedii dell'arte, szczególnie z jej obrazowości, z drugiej - opierała się na badaniach naukowych z zakresu efektywnej organizacji pracy (Fredericka W. Taylora), psychologii (Iwana Pawłowa i jego eksperymentów w zakresie odruchów warunkowych) oraz teorii asocjacyjnych odruchów motorycznych (Władimira Biechtieriewa). Postulat dynamiki i ruchu w teatrze wymuszał konieczność stałego treningu fizycznego, ciało aktora miało stać się instrumentem całkowicie podporządkowanym systemowi gry. Przyszli adepci sceny mogli się uczyć w specjalnie w tym celu założonej szkole Studio, gdzie najważniejsze miejsce zajmowały ćwiczenia biomechaniczne (obok boksu, szermierki, rytmiki, tańca klasycznego, żonglerki, dykcji czy śpiewu). Reżyser wymagał od aktorów umiejętności pracy zespołowej, łączenia przeciwstawnych niekiedy elementów oraz pełnej synchronizacji ruchów, a ponieważ twierdził, że nie słowo jest ważne, tylko ruch aktora i zewnętrzne życie sceny, biomechanika miała za zadanie przekształcić człowieka-aktora w element dzieła sztuki.

》 Życie powstało z ruchu - mówił Meyerhold w rozmowie z Bronisławem Dąbrowskim. - Energia rozbudziła instynkt, a później myśl. W moim teatrze pragnę udowodnić, że piękno życia wypływa z ożywienia materii, $z$ dynamiki mięśni. Słowo jest tylko ostatnim elementem, jak gdyby kwiatem, który wykwitł z niepokoju ciała ${ }^{30}$.

28 K. Peplińska, Kultura, organizacja, technika: biomechanika Wsiewotoda Meyerholda w perspektywie performatycznej, tekst wygłoszony w czasie konferencji Wielka? Reforma? Teatru?, podsumowującej kurs wiodący Otwartego Uniwersytetu Poszukiwań, która odbyła się w Instytucie Grotowskiego 7-8 czerwca 2013 r.; referat dostępny na stronie: http:/www.grotowski.net/performer/performer-7/kultura-organizacja-technika-biomechanika-wsiewoloda-meyerholda-w-perspektywie (stan z 16 czerwca 2018 r.).

29 Z. Tonecki, Teatr Meyerholda, „Wiadomości Literackie” 1932, nr 11, s. 1.

30 B. Dąbrowski, Biomechanika Meyerholda, „Gazeta Artystów” 1934, nr 7, s. 1. 
Spektakl dramatyczny Meyerhold budował według reguł muzycznych, wykorzystując zasady symfonizmu, harmonii i kontrapunktu. Jednak tło akustyczne tworzyły nie tylko dźwięki muzyki, ale cała gama odgłosów towarzyszącym ludziom na co dzień, jak łoskot maszyn, turkot kół czy warkot silników. Doskonałym przykładem organizacji widowiska według zasad sztuki muzycznej jest awangardowy w swojej strukturze Rewizor (z I926 roku), którą to inscenizację Meyerhold określał mianem „realizmu muzycznego”, autorstwo spektaklu zaś przyznawał nie Gogolowi, a sobie ${ }^{3 \mathrm{I}}$. Uważał bowiem, że rolą teatru nie jest przekazywanie cudzych idei, lecz dążenie do wyrażania własnych, czyli za ostateczny kształt dzieła scenicznego wyłączną odpowiedzialność ponosi reżyser.

W koncepcji Meyerholda sala teatralna stanowiła miejsce gry nie tylko dla aktorów, ale także dla widzów. Ci mieli być włączeni do spektaklu, jako współtwórcy i współodtwórcy przedstawienia. Taka wizja wymuszała radykalną zmianę organizacji przestrzeni scenicznej: znikał klasyczny podział na scenę i widownię, nie było miejsca na kurtynę $\mathrm{z}$ tradycyjnymi dekoracjami malowanymi na płótnie, zostawała jedynie otwarta platforma, oświetlana ze wszystkich stron przez reflektory; podesty i umieszczone na nich trójwymiarowe metalowe konstrukcje wpuszczano między widzów, pośród których znajdowali się także statyści zachęcający publiczność do aktywnego udziału. Aktorzy, najczęściej ubrani w identyczne kombinezony, wykonywali skomplikowane, zbiorowe zadania na wielopoziomowych rampach bądź przerzucanych przez widownię pomostach. Surowe kubistyczne lub konstruktywistyczne dekoracje zmieniane były w obecności widzów, przy migocącym świetle kandelabrów rzucających fantastyczne, ruchome cienie potęgujące nastrój przedstawienia.

Teatralne eksperymenty Meyerholda zbiegały się z wielkimi przemianami ustrojowymi w Rosji, z którymi reżyser nie tylko się zgadzał, ale które czynnie wspierał, z zaangażowaniem realizując postulat umasowienia teatru. Jeden $\mathrm{z}$ jego aktorów, Igor Iljinski, po latach wspominał: „[Meyerhold] wzywał nas, byśmy nie tylko nieśli sztukę ludowi, nowym widzom, robotnikom i chłopom, ale byśmy stworzyli teatr odzwierciedlający idee komunizmu, idee, które ożyły po Wielkim Październiku, teatr współbrzmiący z epoką" ${ }^{22}$. To Meyerhold wystawił w Piotrogrodzie Misterium Buffo (1919), polityczną i nowatorską sztukę specjalnie napisaną przez Majakowskiego na pierwszą rocznicę rewolucji. Sztuka po ponownej inscenizacji w stolicy (I92I) „stała się wielkim wydarzeniem teatralnej Moskwy, budząc żywą dyskusję nad modelem i przyszłością nowego teatru radzieckiego"33. Z masowych widowisk Meyerholda warto przypomnieć Upadek caratu (I919), grany przez gwardie

31 N. Piesoczinski, op. cit., s. 27.

32 I. Iljinski, Pamiętnik aktora, tłum. S. Pollak, przedmowa K. Puzyna, Warszawa 1962, s. 106.

33 H. Karwacka, Witold Wandurski, Łódź 1968, s. 59. 
czerwone na dwu przeciwstawionych sobie wielkich estradach, połączonych „drogą manifestacji”, z udziałem tysięcy aktorów i dziesiątków tysięcy widzów; Misterium Pracy Wyzwolonej (1920), inscenizowane przed portalem giełdy w Leningradzie (2000 aktorów), z wykorzystaniem orkiestr, czerwonych sztandarów, czerwonych gwiazd, ogni sztucznych, detonacji, strzałów i hymnów; Zdobycie Pałacu Zimowego (I920), prezentowane w naturalnej scenerii także z użyciem dwóch symbolicznie przeciwstawionych estrad (białej i czerwonej) połączonych mostem, przy udziale 6000 grających i 150000 widzów $^{34}$. Artysta nie wahał się również aktualizować teksty sztuk i w usta ich bohaterów wkładać komunikaty o bieżącej sytuacji na frontach (Zorze Verhaerena).

$\mathrm{Na}$ żadnym z pięciu najważniejszych reformatorów rosyjskiego teatru rewolucja nie odcisnęła takiego piętna jak na Meyerholdzie. Najpierw wyniosła go na szczyt, stawiając w roku 1920 roku na czele ruchu „Teatralny Październik”, którego celem było wykorzystanie teatru do walki klasowej. Pierwszy etap tej działalności napotykał na trudności, ponieważ masowa publiczność nie była w stanie zrozumieć nowatorstwa Meyerholda i nie dostrzegała w jego teatrze niczego proletariackiego. Robotnicy buntowali się przeciwko przedstawieniom, a przeprowadzone ankiety wykazały, że marzą oni o dawnym iluzyjnym teatrze z malowaną dekoracją i repertuarem wodewilowo-operetkowym ${ }^{35}$. Powszechnie uważano, że na klęsce tego etapu zaważyła wirtuozeria techniczna jego prekursora. Końcowym etapem było oskarżenie Meyerholda o zdradę w okresie czystek stalinowskich, uwięzienie i śmierć w obozie w 1940 roku.

Publicyści interesowali się nie tylko bieżącymi pracami, ale także losem Meyerholda. Pierwszym w Polsce opracowaniem poświęconym twórcy rewolucyjnego teatru radzieckiego było studium monograficzne Witolda Wandurskiego, opublikowane w kilku kolejnych numerach „Życia Teatru”, w którym autor przedstawił rozwój drogi artystycznej Meyerholda od naturalizmu, przez symbolizm, do konstrukcjonizmu i biomechaniki ${ }^{36}$. Warszawskiej prasie nie umknęła słynna inscenizacja Rewizora i jej nieprzychylna recepcja w pismach sowieckich, w których konserwatywna krytyka i część opinii teatralnej protestowała przeciwko znieksztalceniu Gogola, nadto inscenizacja została zgromiona przez czynniki polityczne. Aby usprawiedliwić swoje dzieło, reżyser zorganizował wieczór dyskusyjny, niestety - jak pisano - z powodu zbyt impulsywnego temperamentu nie odniósł sukcesu ${ }^{37}$. Podkre-

34 T. Kudliński, Teatr powszechny..., s. 37.

35 T. Kudliński, Marks w teatrze?, „Zet” 1936, nr 19, s. 3.

36 W. Wandurski, Rewolucja Meyerholda, „Życie Teatru” 1925, nr 38/39, s. 295-299; nr 40, s. 307-309; nr 41, s. 317-318; nr 42, s. 326-330; nr 43, s. 336-337.

37 [B. a.], Sąd nad „Rewizorem”, „Wiadomości Literackie” 1927, nr 9, s. 1. 
ślano, za paryskim tygodnikiem „Zwieno”, że z oryginalnej komedii niewiele zostało, ponieważ w trakcie przeróbki włączono do niej nie tylko wczesne szkice pisarza, ale także rozmaite warianty utworu ${ }^{38}$. W rezultacie powstał montaż na motywach Gogolowskich, zamknięty w I4 epizodach, który, jak wcześniej wspomniano, Meyerhold uznawał za całkowicie autorskie dzieło. Wówczas, szczęśliwie dla reżysera, wielkim jego sprzymierzeńcem okazał się Anatolij Łunaczarski, ówczesny ludowy komisarz oświaty, który skutecznie bronił wizji Meyerholda.

Duże wrażenie na polskich sprawozdawcach wywarło wystawienie na moskiewskiej scenie sztuki Tretiakowa Krzyczcie Chiny. Tytuł, zapożyczony ze znanego wiersza Majakowskiego, wpisywał się w propagandowy charakter utworu, co korespondowało z ówczesnymi przekonaniami samego Meyerholda. Temat wyzysku biednych przez bogatych pokazany w kontekście walki o godność człowieka stawał się wymarzonym materiałem dla teatralnych eksperymentów zaangażowanego politycznie twórcy ${ }^{39}$. Informowano również o przygotowaniach Meyerholda do wystawienia Damy Kameliowej Dumasa, osadzonej w ramach konwencji dramatu społecznego. Dla jego wyeksponowania poczyniono w adaptacji daleko idące zmiany, począwszy od przeniesienia akcji w epokę po Komunie Paryskiej (podczas gdy u Dumasa toczy się około I840 roku), po wprowadzenie roli oskarżyciela publicznego, z tekstem zaczerpniętym z dzieł Balzaca i Flauberta. Zadaniem tej ostatniej zmiany było podkreślenie konfliktu społecznego. Zwracano uwagę na szeroki zakres gruntownych badań poprzedzających wystawienie sztuki, w tym wyjazd Meyerholda do Paryża w celu dokładnego rozpoznania miejsc akcji oraz zebrania niemal kompletu recenzji z przedstawień Damy Kameliowej w Rosji i Europie ${ }^{40}$. Premiera sztuki z Zinajdą Reich w roli tytułowej odbyła się na deskach Teatru im. Meyerholda (i9 marca I934 roku), jednak inscenizacja nie znalazła uznania w oczach krytyki, a niektórzy traktowali ją nawet jako regres artystyczny wybitnego reżysera ${ }^{4 \mathrm{~T}}$.

Odnotowywano wszelkie, nierzadko kontrowersyjne, poczynania Meyerholda, jak choćby oryginalny sposób na uczczenie dziesiątej rocznicy rewolucji. Artysta zorganizował uliczny happening, którego celem było przypomnienie najbardziej znienawidzonych symboli carskiej władzy: ucisku i przemocy. Przebrał niemal trzystu aktorów za więźniów politycznych, nałożył im kajdany i urządził pochód po ulicach Moskwy ${ }^{42}$. Wnikliwi obserwatorzy sceny politycznej dość szybko dostrzegli sygnały świadczące o narastającej niechęci do zbyt niezależnego twórcy. Ataki

38 [B. a.], Rewizor u Meyerholda, „Wiadomości Literackie” 1927, nr 7, s. 2.

39 J. Hempel, op. cit., s. 2.

40 [B. a.], „Dama Kameliowa” u Meyerholda, „Wiadomości Literackie” 1934, nr 3, s. 5.

41 B. Dąbrowski, Mezalians Meyerholda $i$ - spotkanie ze Stanistawskim..., s. 6.

42 [B. a.], Meyerhold a dziesiąta rocznica rewolucji, „Wiadomości Literackie” 1927, nr 14, s. 3. 
nasiliły się wkrótce po wystawieniu Rewizora, a reżyser stał się tematem satyrycznych publikacji zamieszczanych w „Izwiestiach”, które przedstawiały go jako reakcjonistę i „rycerza ciemnoty”43. W następnych latach oskarżenia przybierały na sile, a najcelniejsze z nich sięgały do źródeł animozji klasowych, insynuując, że jego teatr „nie jest teatrem proletariatu, lecz teatrem estetyzującej burżuazji”"44. Sugestie tej natury w zasadzie przesądzały o przyszłości reżysera. Niebawem na mocy postanowienia Komitetu do spraw Sztuki przy Radzie Komisarzy Ludowych ZSRR doszło do zamknięcia Teatru Meyerholda w Moskwie jako obcego sztuce radzieckiej (1938). Decyzję uzasadniano tym, że jego twórca uległ formalizmowi, wystawiał dwuznaczne sztuki współczesne fałszujące obraz rzeczywistości radzieckiej, nie grał w ostatnich latach radzieckiego repertuaru, a na dwudziestą rocznicę rewolucji przygotował adaptację Jak hartowała się stal, która fałszuje powieść Ostrowskiego i świadczy o postawie antyradzieckiej ${ }^{45}$. Komuniści obwiniali Meyerholda, że przez i8 lat działalności nie mógł się uwolnić od „burżuazyjnego i formalistycznego stanowiska obcego sztuce sowieckiej", a w kierowanym przez niego teatrze nawet klasyczne sztuki wystawiano w formie „skażonej”, natomiast inscenizacje sztuk współczesnych „robiły wrażenie raczej paszkwilu na rzeczywistość sowiecką"46. Przed aresztowaniem nie uchronił Meyerholda nawet przyznany w I923 roku zaszczytny tytuł „artysty ludowego”. Po kilkumiesięcznych przesłuchaniach Kolegium Wojskowe Sądu Najwyższego skazało go na śmierć (2 lutego I940 roku) pod zarzutem działalności antysowieckiej i trockistowskiej.

Teoretykiem syntetyzującym dwa przeciwstawne kierunki był kolejny wybitny uczeń Stanisławskiego - Eugeniusz Wachtangow, który starał się łączyć elementy naturalizmu mistrza z zewnętrznym formalizmem Meyerholda. Poszukiwał w teatrze „współczesnych sposobów nadania widowisku formy”, a swoje dążenia w tym zakresie określił mianem „realizmu fantastycznego”, ponieważ pragnął stworzyć dzieło teatralne, które nie byłoby ani naturalistyczne, ani realistyczne, ale powszechnie dostępne „rozumieniu wszystkich narodów” ${ }^{47}$. Podczas krótkiej praktyki teatralnej zerwał z iluzjonizmem perspektywicznym, potwierdził teatralizację i uznał scenę trójwymiarową. Stworzył cztery wybitne spektakle, a dwa z nich przeszły do historii: Dybuk Szymona An-skiego i Księżniczka Turandot Carlo Gozziego, do której czerpał wzory inscenizacyjne z komedii dell'arte. Księżniczka Turandot

43 [B. a.], Walka z Meyerholdem, „Wiadomości Literackie” 1927, nr 14, s. 3.

44 (mdd) [M. Dienstl-Dąbrowa], Moskiewski reżyser Meyerhold nie chce być agitatorem komunistycznym, „Ilustrowany Kurier Codzienny” 1936, nr 107, s. 9.

45 J. Koenig, Pię́́dziesiąt lat teatru ZSRR (1917-1967), „Pamiętnik Teatralny” 1967, z. 3-4, s. 336.

46 [B. a.], Dlaczego bolszewicy zamknęli Teatr Meyerholda?, „Ilustrowany Kurier Codzienny” 1938, nr 11, s. 7.

47 E. Wachtangow, Z pism. Z rozmów z uczniami, „Pamiętnik Teatralny” 1961, nr 2, s. 180-183. 
była ostatnim, przedśmiertnym dziełem artysty, który posłużył się w niej chwytem teatru w teatrze. Aktorzy nie grali postaci ze sztuki Gozziego, ale włoskich aktorów przedstawiających bajkę ${ }^{4}$.

Podobnie jak Wachtangow również Aleksandr Tairow stworzył syntezę, ale w odróżnieniu od poprzednika, zanegował dorobek Stanisławskiego, skupiając się wyłącznie na możliwościach środków technicznych sceny wspomagających aktora w jego ekspresji artystycznej. Tym gestem wypowiedział otwartą wojnę teatrowi naturalistycznemu i, postulując nowe kanony sztuki scenicznej, postanowił ostro rozprawić się z dotychczasowym autorytetem. Zbudował nawet hierarchię w zależności od metody pracy stosowanej na scenie. „Na najniższym stopniu według Tairowa stoi teatr przeżywania - Teatr Stanisławskiego. Drugi etap, wyższy, jest to teatr wolny, teatr umawiania się co do założeń artystycznych. Na najwyższym stopniu teatralności stoi Teatr Kameralny, którego hasłem jest teatralizacja teatru"49. Całą ideologię w tej materii znajdziemy w Zapiskach reżysera (wydanych nakładem moskiewskiego Teatru Kameralnego w I92I roku), w których twórca głosił, że aktor nie może mieć żadnych szczerych przeżyć, nie powinien też ani przez chwilę zapominać, że jest na scenie, aby odbiorca nawet przez moment nie pomyślał, że to, co widzi, zna już z własnego doświadczenia. Rozdzielane dotychczas sztucznie elementy sztuki spektaklu: słowa, śpiew, pantomina, taniec, u niego splatają się ze sobą, tworząc jedyny „monolitowy” utwór teatralny ${ }^{50}$. Syntezę sceniczną tworzą zdaniem Tairowa - emocjonalny gest i emocjonalna forma, poza którą nie dostrzegał drogi rozwoju dla ówczesnego teatru, a nawet dla teatru w ogóle. Innymi słowy, dla tego artysty istniała wyłącznie zewnętrzna, widowiskowa strona teatru. Nowatorstwo twórcy Teatru Kameralnego polegało na odkryciu, że teatr jest interpolacją misterium i arlekinady, zatem to wyłącznie wszechstronny aktor winien skupiać na sobie uwagę publiczności. Uważał też, że nadszedł już czas, by aktorzy zamiast naturalistycznego przeżywania zaczęli pokazywać na scenie teatralne mistrzostwo, gdyż dotychczasowa sztuka teatralna zbyt duży nacisk kładła na treść, a jego zdaniem aktor powinien być przesiąknięty „li tylko formą”. Od adeptów sztuki scenicznej wymagał nieustannego ćwiczenia ruchu, ciała i głosu, gdyż aktor nowego typu miał stać się wirtuozem artystycznego rzemiosła, a jego ciało - instrumentem zdolnym do odegrania każdego rytmu. Aby osiągać jak najlepsze rezultaty, zapraszano do współpracy akrobatów cyrkowców, których zadaniem było doprowadzenie „materiału cielesnego" do doskonałości. W polu widzenia tego reżysera zawsze były

48 K. Osińska, Leksykon teatru rosyjskiego XX wieku, Warszawa 1997, s. 69.

49 J. Miciński, Aleksandr Tairow. Zapiski reżysera..., „Życie Teatru” 1925, nr 21, s. 176.

50 W. de Bondy, „Teatr Kameralny” w Moskwie. (Kamiernyj tieatr), „Tygodnik Ilustrowany” 1922, nr 45, s. 723 . 
obecne ciało, ruch, poza, gest, a także kostium, który kształtem, barwą i krojem miał uwydatniać narzucony przez inscenizatora rytm.

Podobnie jak u Meyerholda także w koncepcji Tairowa ważnym elementem była organizacja sceny, która sprawiała wrażenie skromnego malarsko geometrycznego szkieletu wypełnionego schodami, stopniami, łukami czy platformami rozłożonymi na różnych płaszczyznach ${ }^{51}$. $Z$ czasem ten reformator rosyjskiej sceny stał się teoretykiem i twórcą nowego kubistycznego teatru ${ }^{52}$. Widowiska wypełniały muzyka, przestrzenne konstrukcje oraz bogactwo form scenicznych od operetki, przez akrobatykę, po klasyczną tragedię. Głównym celem tak budowanej formy teatralnej było to, aby widz w każdej sekundzie mógł się cieszyć „harmonią kolorów, ruchu, dźwięku, pozostawiając dla duszy jedynie możność estetycznego lubowania się tą harmonią" 53 , i wychodząc $z$ teatru, odczuwał wyłącznie pełną gamę wrażeń estetycznych. Tym samym reżyser zrywał z Arystotelesowską zasadą greckiego teatru, opierającą się na zdolności wzruszania.

Hołdujący wyłącznie widowiskowej stronie teatru Tairow nie potrafil odnaleźć drogi ku misterium. Przykładem odsłaniającym tego typu problemy było wystawienie Zwiastowania Claudela (I920), drugiej po rewolucji sztuki nieznanego dotąd w Rosji współczesnego autora francuskiego (pierwszą była Zamiana, I918), i $S a-$ kuntali Kalidasy, w których istotne elementy mistyczne zostały odsunięte na drugi plan. To pokazało, że teatr formistyczny Tairowa funkcjonuje na przeciwstawnym biegunie wobec teatru Stanisławskiego.

Nieco inną drogę wybrał Nikołaj Jewreinow, dyrektor literacki petersburskiego rewiowego teatrzyku Krzywe Zwierciadło. Jako praktyk i teoretyk teatru opowiadał się za teatralizacją i kreacją. Artysta swobodnie mieszał konwencje gatunkowe, czerpiąc z osiągnięć zarówno dramatu wizyjnego, jak mistycznego. Stworzył teorię życia jako gry, życia jako teatru, którego bohaterem jest homo ludens. Autor sztuki To, co najważniejsze odwoływał się do przedestetycznego instynktu teatralnego, rozumiał teatr jako coś, co jest tak samo niezbędne człowiekowi jak ruch, jedzenie, miłość. Teatr miał być zabawą, grą, ciągłą przemianą, tak jak życie w swej najgłębszej warstwie jest $\mathrm{w}$ istocie teatrem. Zadaniem artysty było więc ukazywanie teatralności życia.

Już na moskiewskiej scenie Teatru Dramatycznego sztuka Jewreinowa To, co najważniejsze zachwyciła polskiego sprawozdawcę, Romana Dyboskiego, który w I92I roku udał się do Moskwy z misją dyplomatyczną w sprawie repatriacji Po-

51 R. Ordyński, O wyzwolenie teatru, „Wiadomości Literackie” 1925, nr 46, s. 3; B. Wieczorkiewicz, Od Stanistawskiego do Sachawy, „Życie Teatru” 1922, nr 5, s. 37.

52 W. Husarski, Inscenizacja Achilleidy, „Życie Teatru” 1925, nr 48/49, s. 369.

53 J. Chodecki, „Zwiastowanie” u Tairowa, „Listy z Teatru” 1924, nr 4, s. 118. 
laków z ziem dawnego Imperium. $Z$ jego relacji wynika, że mimo uprzedzenia do wszystkiego co rosyjskie, a zwłaszcza do „bolszewizmu” (miał po temu powód, bo jako jeniec wojenny spędził na Syberii siedem lat), sztuka Jewreinowa nie tylko zafascynowała go, ale także wprawiła w zdumienie. Powodem oczarowania była wiara jej autora w terapeutyczną moc teatru: „mocna, zdrowa wiara w społeczną doniosłość teatru, w dobroczynność sztuki dla człowieka" - podkreślał Dyboski ${ }^{54}$. Twórca Tego, co najważniejsze zdaje się mówić, że iluzja jest niezbędna człowiekowi, wzbogaca jego życie, potrafi go uszlachetnić. Za jej sprawą może on odnosić zwycięstwo nad cierpieniem i nędzą, może też zyskać upragnione szczęście. Stworzona przez Jewreinowa postać Parakleta, czyli Ducha-Pocieszyciela, to spiritus movens wszystkich wydarzeń, które pokazują, jak dalece można wpływać na los innych, uczynić go choć na chwilę lepszym. Przed wiekami widzów historycznego teatru The Globe w Londynie witał napis „Cały świat gra komedię” $i$ do tej właśnie maksymy wraca Jewreinow. Jego bohaterowie na scenie życia także grają komedię. Okazuje się, że każdy z nich w rzeczywistości jest kimś innym: owładnięty manią samobójczą student ukrywa przed ojcem tajemnicę tragicznej śmierci brata; bajecznie bogaty amerykański przedsiębiorca, Doktor Fregolli, ongiś popełnił zbrodnię wielożeństwa i chce to naprawić; skrzywdzone kobiety szukają namiastki szczęścia. Wszyscy pragną odmiany swojego losu, chętnie biorą udział w inicjowanych działaniach, nawet jeśli domyślają się, że to tylko gra. Zanurzają się w świat teatralnej rzeczywistości, ponieważ w człowieku tkwi naturalna skłonność do szukania szczęścia w złudzeniach, iluzji, a nawet w bajce upiększającej szarzyznę życia.

Polska prapremiera sztuki odbyła się w Krakowie na scenie Teatru im. J. Słowackiego w 1922 roku. W następnym roku pojawiła się także w repertuarze stołecznego Teatru Polskiego w reżyserii Borowskiego i z dekoracjami Frycza. Jej nowatorską myśl, zawierającą się w idei „teatralizacji życia”, i jej odmienność na tle dominujących mód teatralnych dostrzegł Anatol Stern. „To mistyka teatralności, mistyka w jej najistotniejszej formie, przemawia do nas ze sceny. Inscenizowana «teoria instynktu przemiany», której zrealizowanie daje istotną radość nadania twórczej treści życiu” - pisał na łamach „Skamandra” ${ }^{5}$, choć jednocześnie surowo ganił Teatr Polski za całkowite wypaczenie przesłania sztuki. Uważał, że reżyser nie tylko nie podjął idei przewodniej utworu Jewreinowa, ale potraktował „naturalistycznie sztukę zaciętego wroga naturalizmu i kazał grać naturalistycznie bohaterom jej, wyśmiewającym teatr naturalistyczny" ${ }^{16}$. Mimo tak surowego sądu sztuka zaskarbiła sobie

54 R. Dyboski, op. cit., s. 212.

55 A. Stern, Teatr, „Skamander” 1923, nr 28, s. 53.

56 Ibidem. 
uwagę publiczności i nie schodziła ze sceny przez 53 wieczory ${ }^{57}$. Wkrótce znalazła się na afiszach teatrów Łodzi, Lwowa, Lublina, Torunia, Wilna, Grodna i Łucka.

Pięciu wielkich rosyjskich artystów żyjących na przełomie wieków i doświadczających skutków radykalnych przemian ustrojowych było uważnie obserwowanych nie tylko przez polskich publicystów, ale także przez ludzi kultury, żywo zainteresowanych przemianami politycznymi zachodzącymi w Kraju Rad oraz ich wpływem na kulturę i sztukę. Pełną percepcję zakłócało często stereotypowe myślenie na temat Rosjan, ukształtowane doświadczeniem zaborów, a także dramatyczne relacje z wydarzeń rozgrywających się za wschodnią granicą. Mimo niesprzyjającej koniunktury politycznej w Polsce ludzie teatru $z$ uwagą analizowali nowe trendy artystyczne pojawiające się w obu stolicach dawnego Imperium. Zauważona i doceniona została oryginalność dzieła Meyerholda, ekscentryczność wizji Tairowa, odkrywczość spojrzenia Jewreinowa, groteskowa drapieżność Wachtangowa czy głęboko zakorzeniona idea wierności autorowi Stanisławskiego. Szczególnie rola tego ostatniego jako wielkiego mentora i inspiratora działań artystycznych nie tylko swoich wychowanków wydaje się nie do przecenienia. Zestawienie idei, dokonań i przemyśleń tych twórców pokazuje,jak ważne stanowili dla siebie nawzajem punkty odniesienia i jak skomplikowane łączyły ich stosunki, niewolne od antagonistycznych posunięć.

\title{
BiBLIOGRAFIA:
}

\section{DRUKI ZWARTE:}

Iljinski I., Pamiętnik aktora, thum. S. Pollak, przedmowa K. Puzyna, Warszawa 1962;

Karwacka H., Witold Wandurski, Łódź 1968;

Krasiński E., Warszawskie sceny 1918-1939, Warszawa 1976;

Osińska K., Leksykon teatru rosyjskiego XX wieku, Warszawa 1997;

Pollak S., Srebrny wiek i później, Warszawa 1971;

Stanisławski K., Moje życie w sztuce, tłum. Z. Petersowa, Warszawa 1951;

Wisner W., Z historii stosunków kulturalnych polsko-radzieckich 1919-1939, Warszawa 1987;

Zelwerowicz A., Gawędy starego komedianta, Warszawa 1958.

\author{
ARTYKUEY: \\ [B. a.], „Dama Kameliowa” u Meyerholda, „Wiadomości Literackie” 1934, nr 3, s. 5; \\ [B. a.], Dlaczego bolszewicy zamknęli Teatr Meyerholda?, „Ilustrowany Kurier Codzienny” 1938, nr 11, s. 7; \\ [B. a.], Meyerhold a dziesiąta rocznica rewolucji, „Wiadomości Literackie” 1927, nr 14, s. 3; \\ [B. a.], Moskiewski Teatr Artystyczny, „Kurier Literacko-Naukowy” 1926, nr 19 (127), s. 4;
}

57 E. Krasiński, Warszawskie sceny 1918-1939, Warszawa 1976, s. 104. 
[B. a.], Na występy do Moskwy jedzie z Warszawy zespót 40 artystów, „Republika” 1934, nr 192, s. 4;

[B. a.], Podróże teatru Stanistawskiego, „Życie Teatru” 1922, nr 2, s. 15;

[B. a.], Rewizor u Meyerholda, „Wiadomości Literackie” 1927, nr 7, s. 2;

[B. a.], Sąd nad „Rewizorem”, „Wiadomości Literackie” 1927, nr 9, s. 1;

[B. a.], Statystyka teatru sowieckiego, „Wiadomości Literackie” 1935, nr 14, s. 3;

[B. a.], Sztuka o Petlurze, „Wiadomości Literackie” 1926, nr 18, s. 3;

[B. a.], Walka z Meyerholdem, „Wiadomości Literackie” 1927, nr 14, s. 3;

Bondy W. de, „Teatr Kameralny” w Moskwie. (Kamiernyj tieatr), „Tygodnik Ilustrowany 1922, nr 45, s. 723;

Chodecki J., „Zwiastowanie” u Tairowa, „Listy z Teatru” 1924, nr 4, s. 118;

Dąbrowski B., Biomechanika Meyerholda, „Gazeta Artystów” 1934, nr 7, s. 1;

Mezalians Meyerholda i - spotkanie ze Stanistawskim. (Obrazki z Festiwalu w Moskwie), „Chwila” 1934, nr 26, s. 6;

[Dienstl-Dąbrowa M.], Moskiewski reżyser Meyerhold nie chce być agitatorem komunistycznym, „Ilustrowany Kurier Codzienny" 1936, nr 107, s. 9;

Dyboski R., Wrażenia z teatrów moskiewskich, „Przegląd Warszawski” 1922, nr 5, s. 205;

Hempel J., Propaganda sztuki u naszych wschodnich sąsiadów. Teatr i kino w Rosji sowieckiej, „Wiadomości Literackie" 1926, nr 18, s. 2;

Hiż T., Ryszard Bolestawski w Rosji, „Scena Polska” 1937, z. 1-4, s. 51;

Husarski W., Inscenizacja Achilleidy, „Życie Teatru” 1925, nr 48/49, s. 369;

Jabłonkówna L., Reżyser Mironow o Teatrze im. Wachtangowa, „Wiadomości Literackie” 1934, nr 32;

Jaracz S., Krzewienie kultury teatralnej, „Wiadomości Literackie” 1934, nr 39, s. 4.

Koenig J., Pięćdziesiąt lat teatru ZSRR (1917-1967), „Pamiętnik Teatralny” 1967, z. 3-4, s. 336;

Kudliński T, Marks w teatrze?, „Zet” 1936, nr 19, s. 3;

Teatr powszechny, „Przegląd Współczesny” 1937, t. 60, s. 37;

Lorentowicz J., List otwarty do p. Stanistawskiego, dyrektora teatru rosyjskiego, „Nowa Gazeta” 1906, nr 213, s. 2; Miciński J., Aleksandr Tairow. Zapiski reżysera..., „Życie Teatru” 1925, nr 21, s. 176;

Ordyński R., O wyzwolenie teatru, „Wiadomości Literackie” 1925, nr 46, s. 3;

Pajączkowski F., Konstanty Stanistawski i jego wizyta w Polsce, „Ruch Słowiański” 1938, nr 12, s. 217-219;

Peplińska K., Kultura, organizacja, technika: biomechanika Wsiewotoda Meyerholda w perspektywie performatycznej, tekst wygłoszony w czasie konferencji Wielka? Reforma? Teatru?, podsumowującej kurs wiodący Otwartego Uniwersytetu Poszukiwań, która odbyła się w Instytucie Grotowskiego 7-8 czerwca 2013 r.; referat dostępny na stronie: http:/www.grotowski.net/performer/performer-7/kultura-organizacja-technika-biomechanika-wsiewoloda-meyerholda-w-perspektywie (stan z 16 czerwca 2018 roku);

Piesoczinski N., Wsiewotod Meyerhold. Teoria względności, tłum. A. L. Piotrowska, „Pamiętnik Teatralny” 2001, z. 3-4, s. 8 i inne;

[Popławska Z.] Z.P. , Z teatrów, „Bluszcz” 1926, nr 6, s. 176;

Rabski W., Z teatru, „Kurier Warszawski” 1906, nr 128, s. 2;

Słonimski A., Moskiewski teatr artystyczny w Warszawie, „Wiadomości Literackie” 1929, nr 21, s. 4;

Stanisławski K., Myśli o twórczości aktorskiej, tłum. W. Melcer, „Scena Polska” 1938, z. 2/3, s. 310;

Stern A., Teatr, „Skamander” 1923, nr 28, s. 53; 
Tonecki Z., Teatr Meyerholda, „Wiadomości Literackie” 1932, nr 11, s. 1;

Wachtangow E., Z pism. Z rozmów z uczniami, „Pamiętnik Teatralny” 1961, nr 2, s. 180-183;

Wandurski W., Rewolucja Meyerholda, „Życie Teatru” 1925, nr 38/39, s. 295-299; nr 40, s. 307-309; nr 41, s. 317-318; $\mathrm{nr} 42$, s. 326-330; $\mathrm{nr}$ 43, s. 336-337;

Wieczorkiewicz B., Od Stanistawskiego do Sachawy, „Życie Teatru” 1922, nr 5, s. 37;

Zelwerowicz A., Święto teatralne w Moskwie, „Tygodnik Ilustrowany” 1928, nr 47, s. 870.

SŁowa KLUCZE: reformatorzy rosyjskiego teatru, dwudziestolecie międzywojenne, recepcja, Stanisławski, Meyerhold, Jewreinow, Tairow, Wachtangow

\section{ГРАЖИНА ПАВАЯК}

ТЕАТРААЬНАЯ РОССИЯ НА СТРАНИЦАХ МЕЖВОЕННОЙ ПОАЬСКОЙ ПРЕССЫ. СОВЕТСКИЙ ТЕАТР И ЕГО СОЗААТЕАИ

В статье обрисована картина взаимовцияний межАу польским и русским театром с начала XX века. Упоминаются выдающиеся реформаторы русской театральной сцены, Аичности и достижения которых во много повцияли на развитие польского театра.

КАючевЫЕ САОвА: реформаторы русского театра, межвоенное время, рецепция, Станиславский, МейерхольА, Евреинов, Таиров, Вахтангов

\section{Grażyna PAWLAK}

Theatre rossica in Interwar Poland's Press. Soviet Theatre and ITS CREATORS

The text outlines the image of artistic influences between Polish and Russian theatre, dating back to the beginning of the twentieth century. It also presents the figures of outstanding reformers of the Russian stage, whose prominence and achievement had a significant influence on the style of Polish theatre.

KEYwoRds: reformers of the Russian theatre, the interwar period, reception, Stanisławski, Meyerhold, Evreinov, Tairov, Vakhtangov 